\title{
Dealing with variability in water availability: the case of the Verde Grande River basin, Brazil
}

\author{
B. COLLISCHONN, A. V. LOPES \& A. R. PANTE \\ Agência Nacional de Águas, Setor Policial, área 5, quadra 3, bloco L, 70610-200 Brasília (DF), Brazil \\ bruno.collischonn@ana.gov.br
}

\begin{abstract}
This paper presents a water resources management strategy developed by the Brazilian National Water Agency (ANA) to cope with the conflicts between water users in the Verde Grande River basin, located at the southern border of the Brazilian semi-arid region. The basin is dominated by water-demanding fruit irrigation agriculture, which has grown significantly and without adequate water use control, over the last 30 years. The current water demand for irrigation exceeds water availability (understood as a 95\% percentile of the flow duration curve) in a ratio of three to one, meaning that downstream water users are experiencing more frequent water shortages than upstream ones. The management strategy implemented in 2008 has the objective of equalizing risk for all water users and consists of a set of rules designed to restrict water withdrawals according to current river water level (indicative of water availability) and water demand. Under that rule, larger farmers have proportionally larger reductions in water use, preserving small subsistence irrigators. Moreover, dry season streamflow is forecasted at strategic points by the end of every rainy season, providing evaluation of shortage risk. Thus, water users are informed about the forecasts and corresponding restrictions well in advance, allowing for anticipated planning of irrigated areas and practices. In order to enforce restriction rules, water meters were installed in all larger water users and inefficient farmers were obligated to improve their irrigation systems' performance. Finally, increases in irrigated area are only allowed in the case of annual crops and during months of higher water availability (November to June). The strategy differs from convectional approached based only on water use priority and has been successful in dealing with natural variability of water availability, allowing more water to be used in wet years and managing risk in an isonomic manner during dry years.
\end{abstract}

Key words water resources management; variability; water rights enforcement

\section{BACKGROUND}

\section{Legal and technical issues regarding water rights in Brazil}

Brazil is a country generally associated with water abundance, largely because of the Amazonian basin, which contains around $15 \%$ of all global freshwater (Goulding et al. 2003). However, other regions in Brazil face more pressure for water use. In fact, the metropolitan regions in the southeast and the dry portions of the northeast show critical water resources imbalances due to both limited natural water availability and growing water demands. Those regions require specific and innovative water management strategies to cope with uncertain hydrologic behaviour and inefficient water use, without compromising the expansion of economic activity.

As a developing country, water use patterns in Brazil change very fast, with farmland frontiers developing in several regions (The Economist 2013). The Brazilian Water Resources Policy is still relatively young, as the current legal framework was only set up in 1997 (reference: federal law n. 9433), forcing the legalization of water uses. Before that, water resources planning and management was fragmented, with each user sector developing its own plans independently. Also, the National Water Agency was established in 2000 with the objective of establishing a National Water Resources System, in a more integrated, basin-oriented approach. But challenges are still to be resolved, remarkably in regions where water conflicts already existed before that period.

In order to divert water from rivers or lakes for any economic activity (urban water supply, industry, irrigation), one must get a water use permit from the corresponding authorities. In Brazilian law these water use permits are known as "outorga". The outorga is a discretionary decision taken by the State, and its concession depends on water use efficiency and water availability. In other terms, the concession of a new outorga must not harm other users with water use rights in the same basin, i.e. multiple uses must be assured. Moreover, water uses must be efficient according to preestablished standards, otherwise the water rights can be cancelled. Irrigation corresponds currently for around 69\% of total water rights allocated in Brazil (National Water Agency 2005). 
In practical terms, water availability is defined, for management purposes, as a share of a highduration flow. At the federal level, ANA generally sets the flow with $95 \%$ permanence as reference, as proposed by Dingman (2002), which is called the reference flow. Thus, a 5\% frequency of failure in the supply is implicitly accepted. This is considered an acceptable level of risk, since most irrigated crops tolerate short water stress periods. In some cases, seasonal reference flows are adopted (typically the flow with $95 \%$ permanence each month), thus allowing more water use during wet months and restricting its use during dry periods (Collischonn and Pante 2011).

This approach of defining a reference flow and granting water rights based on that water availability works well in situations where overall water demand is low in comparison to water availability. But in some situations where demand already exceeds water availability, more sophisticated approaches are needed in order to set priorities among users and proper rules for water shortages.

\section{The Verde Grande River basin}

Our study case area lies in the transition of the more humid Brazilian savannah ("cerrado"), which covers most of central part of the country, and the semi-arid northeast, draining an area of 32000 $\mathrm{km}^{2}$. It includes areas of the northern part of the Brazilian state of Minas Gerais and southern Bahia. Its main river flows through the border with the neighbouring state of Bahia in its final reach, before flowing into the São Francisco River. As the river flows northwards, mean rainfall decreases from $1000 \mathrm{~mm}$ to $700 \mathrm{~mm}$ per year, concentrated in the austral spring and summer periods (October to April). This south-north gradient is related to the position of the South Atlantic Convergence Zone (SACZ), a convective complex originating in the Amazon which is responsible for most of the rainfall in mid-Brazil (Robertson and Mechoso 2000).
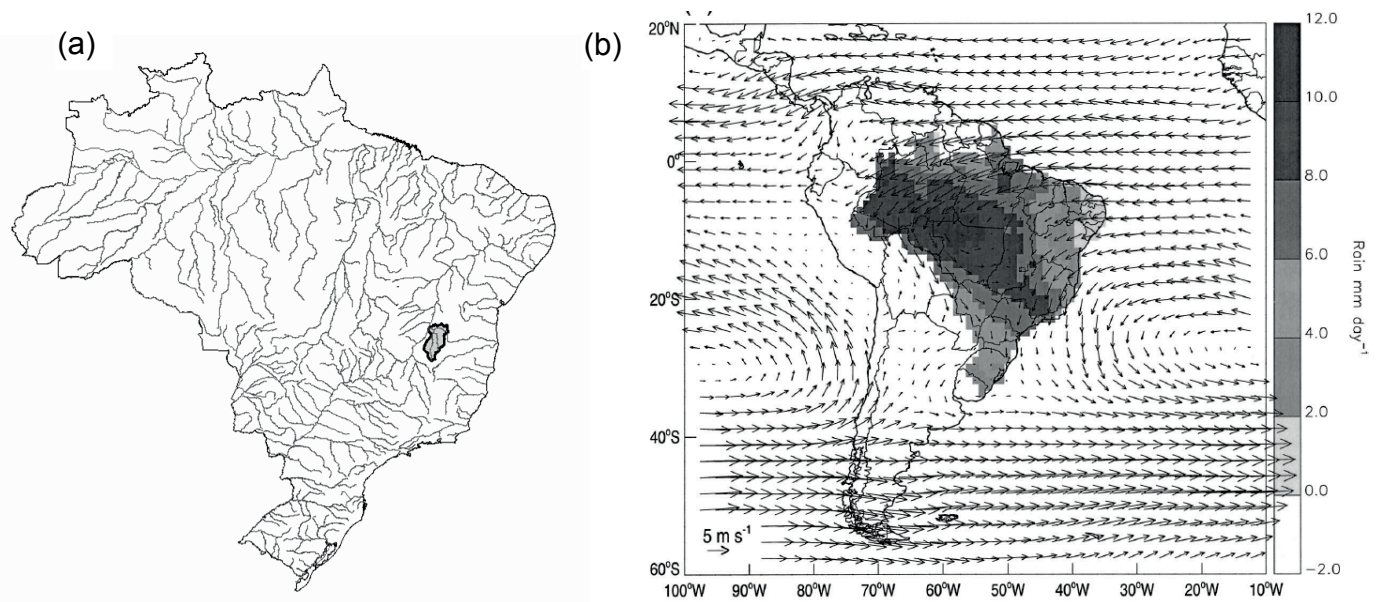

Fig. 1 Location of the Verde Grande River Basin (a) and position and intensity of SACZ rainfall (Carvalho et al. 2003, (b)).

Thus, river flows in the dry season (May-September) depends heavily on the amount of rainfall during the previous rainy season. The Verde Grande River is the only perennial river in the basin and there are no reservoirs along the river to regulate flows. In some years, SACZ develops in a more southwards position, implying in scarcer rainfall over the basin and consequently lower river flows during dry season.

During the early 1980s, government subsidies for irrigation equipment caused an increase of irrigated agriculture in the region. This period coincided with a sequence of wet years, giving a false impression of higher water availability and pushing irrigation to long-term unsustainable levels. Also, that expansion in water use occurred before formal implementation of a Water Resources Policy in Brazil in 1997. Thus, no formal water rights system existed, increasing conflicts for water use. In the late 1990s, a severe dry period led to water shortages and significant economic losses in the basin. 


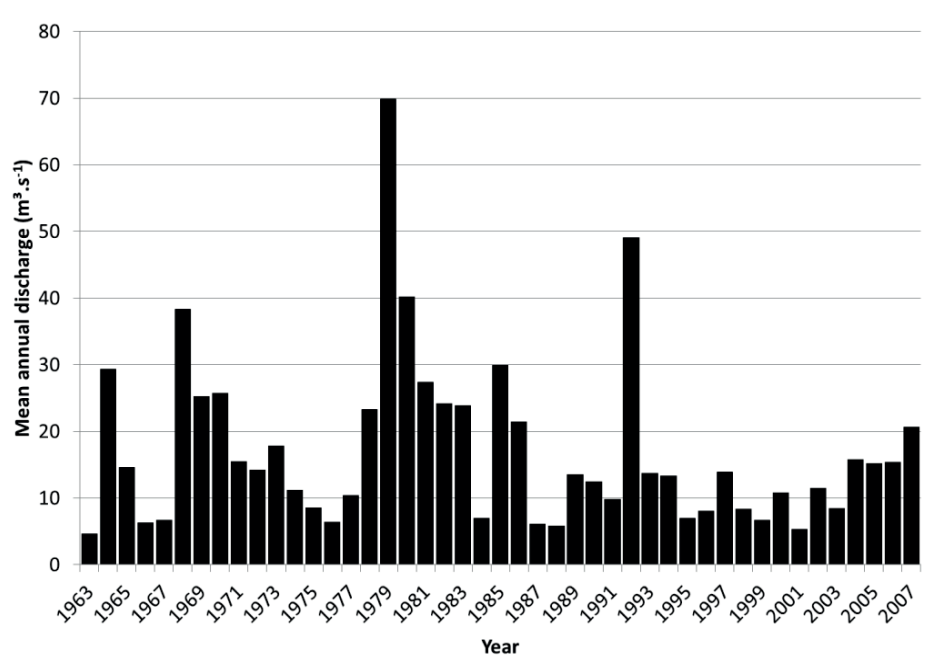

Fig. 2 Mean annual discharge of the Verde Grande River, from 1963 to 2007, showing a wet period preceding the early 1980 s.

Nowadays, the main crops are irrigated fruits, mainly bananas, with part of the crops exported to Europe. Smaller farmers cultivate irrigated subsistence crops, such as corn and beans. The irrigated area supplied by the main river is 3000 hectares. All irrigators are private farmers diverting water directly from the river. Irrigation methods are sprinkling (mainly centre-pivot) and trickle. Still, water users in the basin show low awareness of the legal framework regarding water resources and of the need of obtaining proper water rights. This is why, in 2004, the National Water Agency carried out a field survey to identify water users and quantify water demand. Filled survey forms were considered as water rights requests, initiating a legalization process.

This survey showed that overall water demand exceeded water availability (understood as a $95 \%$ percentile of the flow duration curve) in a ratio of three to one. In fact, total demand corresponded to a streamflow with a duration of $75 \%$ in time, meaning that in $25 \%$ of the time, demands could not be fully met, affecting mainly downstream users. Moreover, given the interannual variability of rainfall and streamflows, the $25 \%$ risk of failure (90 days per year on average) is not evenly distributed among years, meaning that in some years failure to meet demand exceeded three months per year, with obvious losses to irrigated crops, especially perennial ones.

\section{THE WATER RESOURCES MANAGEMENT STRATEGY}

\section{Design of the strategy}

The results of the field survey to quantify demands showed a situation that was not isonomic: while upstream users had their water demand met every year, downstream demands were met only in average or wet years. A first approach to equalize risk would be to cut demands of all users proportionally, until overall demand is equal to water availability. However, this would be an extreme unpopular measure among water users. Moreover, it would reduce production, even in wet years. Instead, the adopted strategy consisted in managing demand on a year-to-year basis, linking demand cuts to water level at a reference river gauge, located upstream of most significant users, so measurements are not affected by water withdrawals.

As mentioned, total demands are fully met for streamflows equal or greater than $\mathrm{Q}_{75 \%}$. For streamflows with higher duration $\left(\mathrm{Q}_{85 \%}, \mathrm{Q}_{95 \%}\right)$ a set of mandatory withdrawal cuts is established, until the reduced demand is equal to the current streamflow. The threshold streamflows for each cut were converted to corresponding water level at the reference gauge, in order to translate the rules into simple level measurements and enhance comprehension. This translated into the rules described in Table 1.

As shown in Table 1, during wet years no restrictions are in place and all users have their demands fully met. However, during dry years all users must restrict water withdrawals in order 
Table 1 Water use rules conditioned on water availability.

\begin{tabular}{lll}
\hline Streamflow interval & Water level interval & Cut rule \\
\hline $\begin{array}{l}\text { Higher than } \mathrm{Q}_{75 \%} \\
\text { Between Q }\end{array}$ & $\begin{array}{l}\text { Higher than } 150 \mathrm{~cm} \\
\text { Between } 140 \mathrm{~cm} \text { and } 150 \mathrm{~cm}\end{array}$ & $\begin{array}{l}\text { Demands fully met } \\
\text { Withdrawals higher than } 50 \mathrm{~m}^{3} / \mathrm{h} \mathrm{must}\end{array}$ \\
be reduced by $20 \%$
\end{tabular}

to share risk equally. Total interruption for streamflows below $\mathrm{Q}_{95} \%$ is needed in order to preserve small subsistence farmers and the cities of Verdelândia and Jaíba who depend on the Verde Grande River for urban supply.

A special concern in designing the strategy was dedicated to small subsistence farmers, with irrigated areas less than 4 hectares. These represented $80 \%$ of the 118 identified water users, but less than $20 \%$ of total demand. Imposing water use restrictions on those farmers would not represent significant gain in water availability. Also, the social and economical impacts on individual small farmers would be far more severe than those larger farmers would experience, given their more robust economic activities. Moreover, enforcement costs would be much larger if a greater number of water users were subjected to restrictions. Thus, focusing the rules on a few large water users would facilitate the practical assessment of water use compliance. Therefore, there are many social, political and management advantages that makes the proposed rules attractive, even with possible overall economic inefficiency, as the larger, most productive water users are the first to be restricted.

The water levels are published daily on the internet at http://cotaonline.ana.gov.br, and bulletins are published twice a month (http://www2.ana.gov.br/Paginas/servicos/saladesituacao/ boletinsmonitoramento.aspx), during the dry period, in order to inform the need of cuts. Moreover, streamflow forecasts are prepared by ANA at the end of the rain season, generally in late may or early June. This forecast is based on a simple exponential recession model of the type:

$$
Q_{t}=Q_{0} \cdot e^{-\alpha t}
$$

where $Q_{t}$ is the forecasted streamflow in $t$ days $\left(\mathrm{m}^{3} / \mathrm{s}\right), Q_{0}$ is the streamflow at the end of the rain season, and $\alpha$ is the recession parameter $\left(\right.$ day $\left.^{-1}\right)$.

The recession parameter $\alpha$ is an average of calibrated values based on several distinct river recessions, resulting in a value of $0.015 \mathrm{day}^{-1}$. A comparison of actual and forecasted streamflows is presented in Fig. 3.

In 2008, the strategy was approved by the river basin committee, a decentralized body in charge of defining water use priorities, where irrigators and urban supply companies have a seat

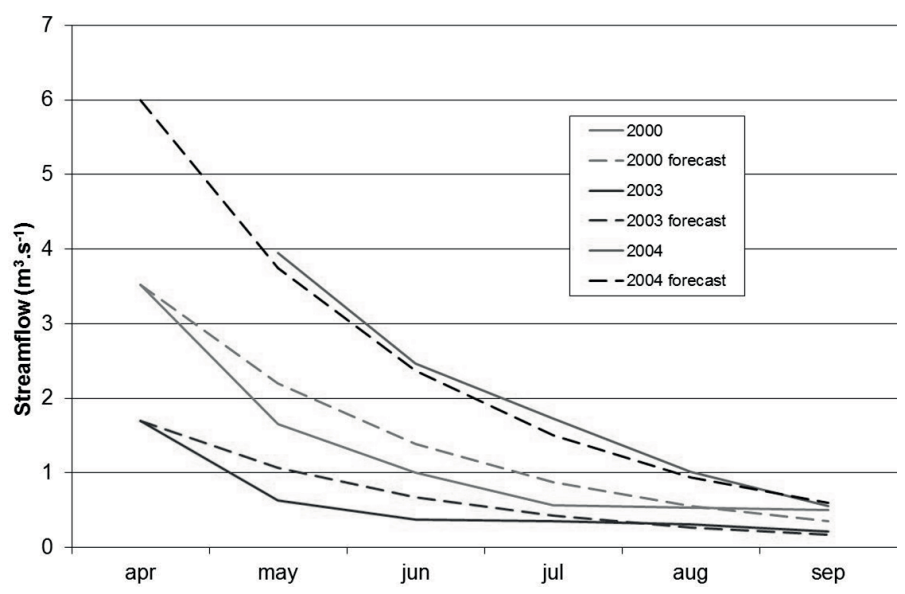

Fig. 3 Recession models adopted. 
(http://www.verdegrande.cbh.gov.br/ docs/deliberacoes/Deliberacao0272008.pdf). Thus, the set of rules was validated among water users. Since then, the strategy is being put in practice.

\section{Enforcement}

Since 2008, water use restrictions were needed in all years except for 2009. In the first years, it has been difficult to enforce restrictions, given the relative remoteness of the basin and technical complexities to control water withdrawals. In fact, the river ran dry due to excessive withdrawals in 2011, showing that users did not comply with the rules.

More recently, larger water users were obligated to install water meters, in order to increase water use compliance, as illustrated in Fig. 4. In 2013, a lack of rainfall caused river levels to get below the 50\%-reduction level for almost 3 months. Thanks to water metering, enforcement became more feasible. In fact, fines were applied to 10 water users who were not complying with the restrictions. Water users with inefficient irrigation systems were also obligated to substitute pipes and to seal earth channels in order to prevent seepages. Inefficient methods such as furrow and flooding are not allowed. Thus, a demand-oriented improvement of water balance is expected.
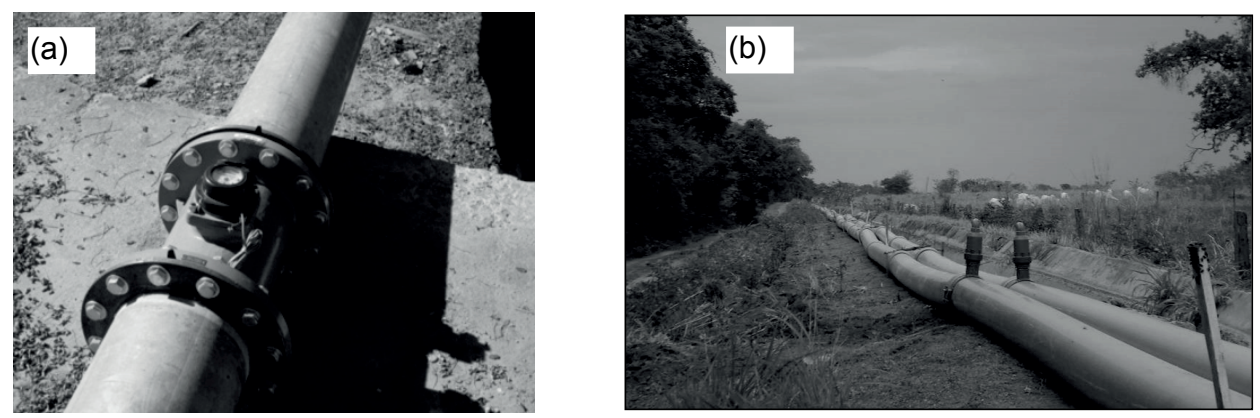

Fig. 4 Water meters for enforcement of restriction rules (a) and improvement of inefficient irrigation systems (b): open channel replaced by pipes.

\section{Alternatives for further expansion of irrigated areas}

Since the strategy has been in place, water rights requests for new irrigated areas have been denied, in order not to further increase conflicts. This has been particularly true for new areas of irrigated fruit (bananas and other perennial crops), which depend on irrigation the whole year round. Approximately 300 hectares of new irrigated areas were not allowed to be implemented.

However, high seasonality of flows in the river means that irrigation is possible during noncritical months, typically November to June. In this period, even with higher mean rainfall, irrigation is still needed because of high evaporation rates. Moreover, small periods of up to two weeks without rainfall are expected, even during rainy months like February, demanding supplemental irrigation.

Thus, water rights requests for new irrigated areas are being granted just in the case of annual crops, typically corn and beans. These crops have had high prices in recent years, thus justifying investment in new irrigation systems even if not cultivating the whole year round. Water rights for such seasonal irrigators totals around 250 hectares.

\section{CONCLUSIONS}

The present paper reports about a strategy carried by ANA, the water resources management agency of Brazil, aiming to pacify a conflict for water use in a river basin with natural variability of water availability.

Withdrawal restrictions are imposed in association with observed streamflow, aimed to share water-related risks equally among all water users when water availability is low. However, in wet years more water is allocated for irrigation. Small subsistence water users are exempt of the need to cut withdrawals, reducing their social and economic costs and facilitating rule enforcement. The 
strategy is a typical command-and-control instrument and results so far are encouraging. Nevertheless, enforcement of such rules is always complex, especially given the relative remoteness of the basin and the early stage of its implementation.

Anticipated flow forecasts allow users to plan irrigation management in advance, meaning that both managers and water users became more resilient to variability. In fact, the rules are flexible enough to allow for an adaptation, even in the presence of more permanent climate change. Also, adoption of seasonal water rights is gradually causing a shift among irrigators, from perennial crops to annual ones, which allows for more flexibility in case of the need of severe restrictions.

The demand-oriented management strategy described in this paper is always hard to apply in practice, because of resistance from water users, low awareness or technical difficulties in its implementation. It also differs from other similar initiatives around the world, like the cap of the Murray-Darling basin in Australia (Pigram 2007), whose aim was to allocate more water for environmental purposes. In this case no instream or environmental flow was foreseen, because of the advanced state of conflict among consumptive users. This was a guideline incorporated in the river basin management plan, developed in an integrated approach with all stakeholders of the basin, since environmental flow requirements could not be met without shutting down several water users, damaging the local economy.

Thus, to our knowledge, this strategy is among the first actually implemented with the focus on adaptation to natural water availability, equal sharing of water use risks, and attenuation of social-economic impacts on small farmers.

\section{REFERENCES}

Carvalho, L. Jones, C. and Liebmann, B. (2003) The South Atlantic convergence zone: intensity, form, persistence, and relationships with intraseasonal to interannual activity and extreme rainfall. Journal of Climate 17, 88-107.

Collischonn, B. and Pante, A. (2011) TRMM-forced rainfall runoff modelling for water management purposes. In: GRACE, Remote Sensing and Ground-Based Methods in Multi-Scale Hydrology (ed. by Mohsin Hafeez). IAHS Publ. 343, 66-71. IAHS Press, Wallingford, UK.

Dingman, S. L. (2002) Physical Hydrology. Waveland, 646 p.

Goulding, M., Barthem, R. B. and Ferreira, E. (2003) The Smithsonian Atlas of the Amazon. Smithsonian Books, Washington.

National Water Agency (2005) Water demand and availability in Brazil. Contributions to the Brazilian National Water Resources Plan. Brasília, $134 \mathrm{p}$.

Pigram, J. (2007) Australian Water Resources. CSIRO Publishing, University of New England, 240 p.

Robertson, A. and Mechoso, C. (2000) Interannual and Interdecadal Variability of the South Atlantic Convergence Zone. Monthly Weather Review - American Meteorological Society 128, 2946-2957.

The Economist (2013) Leave well alone. Edition of 28 September. 